\title{
Peran Pendeta Dalam Mengatasi Kecemasan Jemaat Gereja Kristen Protestenstan Indonesia Onan Runggu Kecamatan Sipahutar Tapanuli Utara Sumatera Utara
}

\author{
Andar Gunawan Pasaribu \\ Prodi Pendidikan Pastoral Konseling, Institut Agama Kristen Negeri Tarutung
}

\begin{abstract}
Abstrak
Tujuan dari penulisan ini adalah untuk mengetahui bagaimana peran pendeta dalam situasi social distancing covid 19. Metode yang digunakan adalah metode kualitatif dan teknik pengumpulan data yang digunakan dengan melakukan tinjauan pustaka dan mengumpulkan data melalui buku dan internet, melakukan pengamatan langsung di bidang objek penelitian yang merupakan peran pendeta dalam berurusan dengan kegelisahan jemaat. Metode yang digunakan pada skala Guttman. Kesimpulan dari peran pendeta dalam mengatasi kegelisahan jemaat dalam situasi social distancing. Gereja adalah sebagai perubahan pola pikir, sebagai motivator untuk melakukan sesuatu yang berbeda, sebagai gembala, sebagai memberi harapan, sebagai penyaringan firman Tuhan melalui whatsapp (WA) dan sebagai pendoa syafaat. Dengan demikian, pembentukan para pendeta dapat menghasilkan: Pertama, anggotaanggota jemaat yang memiliki pengetahuan Firman Allah yang berkualitas baik dan benar sehingga jemaat dapat hidup dalam situasi social distancing yang positif. Kedua, anggota sidang dapat mengatasi kecemasan. Ketiga, dapat menumbuhkan kepercayaan diri dan harapan. Keempat, tantang pendeta untuk meningkatkan perannya dalam situasi social distancing. Hasilnya mencapai $80,85 \%$ peran pendeta dalam mengatasi kegelisahan Gereja dalam situasi social distancing covid 19.
\end{abstract}

Katakunci : Peran Pendeta, Mengatasi mecemasan di situasi social distancing covid 19

\begin{abstract}
The purpose of this writing is to find out how the pastor's role is in the social situation of the 19 corona co-Christian virus distancing. The method used in the writing of this scientific work is a qualitative method and data collection technique used by conducting a literature review by collecting data through books and the internet, making direct observations in the field of the object of study that is the role of the pastor in dealing with the anxiety of the congregation. The method used on the Guttman scale. The conclusion of this scientific work is the pastor's role in overcoming the anxiety of the congregation in social distancing situations (covid virus 19 Corona). The church is as a mindset change, as a motivator to do something different, as a shepherd, as giving hope, as a filterer of God's word through WA and as intercessors. Thus the formation of pastors can produce: First, members of the congregation who have a good and right quality knowledge of God's word so that the congregation can live a positive social distancing situation. Second, members of the congregation can overcome anxiety. Third, can foster confidence and hope. Fourth, challenge the pastor to increase his role. The results achieved $80.85 \%$ the pastor's role in overcoming Church Anxiety in social situations distancing covid corona virus.
\end{abstract}

Keywords: The Pastor's Role, Overcoming anxiety in co-social distancing situations 19

63 | Korespondensi mengenai artikel dapat dilakukan kepada: Andar Gunawan Pasaribu, Institut Agama Kristen Negeri Tarutung, Jl. Raya Tarutung-Siborong KM 11, Silangkitang, Sipoholon, Tapanuli Utara (22452), Indonesia e-mail Corresponding: pdt.andargunawanpasaribu@yahoo.co.id 


\section{PENDAHULUAN}

Segala sesuatu yang terjadi di dunia ini pasti Tuhan tidak lepas tangan. Tuhan mempunyai rencana bagi kehidupan insan yang berserah kepada-Nya . Tuhan pasti berkuasa menyelesaikan setiap masalah yang terjadi di dunia ini. Tuhan tidak membiarkan umatnya binasa. Tuhan menguji setiap umatnya dalam setiap peristiwa untuk membangun dan membentuk kerohanian jemaat. Kerohanian memiliki peran yang menentukan dalam situasi yang sulit. Nilai kerohanian yang diyakini berpotensi berfungsi sebagai potensi kekuatan sehingga mampu bertahan dalam keadaan sulit. Jemaat akan memiliki makna idup dalam keadaan sulit bukan saja berfaedah untuk membingkai pengalaman masa lalu dalam kerangka pemeliharaan Tuhan, ia pun menempatkan masa depan dalam keterarahan dan sekaligus memberi pengharapan akan kebaikan Tuhan.

Tuhan sering menggunakan krisis untuk membawa perubahan yang jatuh tempo dalam hidup kita. Penulis Tony Robbins mengingatkan kita: perubahan terjadi ketika rasa sakit tetap sama lebih besar dari rasa sakit perubahan.

Virus korona tidak mengejutkan Tuhan. Kita tidak boleh menyia-nyiakan musim ini, tetapi kita harus menerimanya dan mengijinkan Tuhan untuk membentuk hidup kita untuk kemuliaanNya. Banyak pendeta dan pemimpin gereja melewati tenggat untuk reset dalam rutinitas rutin mereka. Saya yakin bahwa kita harus mengambil keuntungan dari musim ini untuk menemukan kembali diri kita secara fisik, spiritual dan emosional.

Di dalam masa situasi social distancing, semua pihak sangat diharapan memiliki paritisipasi dan peran yang serius. Memang peran dokter Tidak, perawat atau tenaga medis menjadi garda terdepan dalam melawan corona ini. Medsos begitu cepat memberikan informasi yang global kepada siuasi kehidupan manusia akibat virus corona. Media informasi mempengaruhi kehidupan manusia di situasi social distancing baik dari sisi positip dan negatip. Media social juga mempengaruhi kerohanian jemaat di situasi social distancing.

Untuk itulah kebutuhan yang paling utama dalam kehidupan jemaat dalam proses kerohanian mereka adalah hadirnya seorang pendeta yang sanggup memberikan peran dalam penguatan kerohanian jemaat di situasi social distanting Kemudian dalam peran pendeta, harus memiliki hati yang berkonsentrasi penuh pada jemaat terutama saat jemaat memiliki masalah berat .

\section{Peran Pendeta di Situasi Social Distancing virus covid 19 corona}

Didalam situasi social distancing covid 19 , pemerintah sementara waktu menyatakan di rumah saja (stay at home). Dirumah saja yang dimaksudkan bekerja di rumah, belajar di rumah, dan beribadah di rumah. Sementara waktu warga jemaat beribadah (melakukan ibadah minggu ) di rumah masing masing. Situasi ini membatasi pelayanan dari sang pendeta.

Namun situasi ini tidak membatasi peran sang pendeta. Pendeta melakukan perannya melalui online. Peran Pendeta menurut Estomihi Hutagalung sama dengan apa yang dilakukan oleh John 
Weslye. Estomihi Hutagalung (2020) menyatakan: Bagi John Wesley, kekudusan umat beriman harus berdampak pada realitas hidup berpijak umat beriman. Wesley hendak mendorong keyakinan serta kesadaran orang-orang Methodist dan masyarakat Inggris untuk mengalami, merasakan janji penyertaan Tuhan sebagai Immanuel. Dan buah dari pendampingan dan kesediaan untuk berkorban (involve) tersebutlah yang membangkitkan dan menguatkan iman serta memberi semangat masyarakat Inggris untuk memperoleh kesehatan secara jasmani dan rohani Selanjutnya dalam mengatasi kecemasan ini Butler (1999) menyatakan Ada empat metode utama yang diterapkan, yakni: 1. Mengubah Pola Pikir 2. Melakukan Sesuatu yang Berbeda 3. Mereduksi SelfConciousness 4. Membangun Kepercayaan Diri.Kemudian Agenda GKPI (2015) dalam butir ke 5 menyatakan tugas pendeta memilihar semua orang yang ada yang ada di dalam jemaat.

\section{Sebagai Pengubah Pola Pikir Jemaat}

Pada masa situasi social distancing covid 19, pendeta bertugas membimging kerohanian Jemaat. Kerohanian Jemaat kuat menghadapi situasi social distancing. Pendeta sebagai membimbing rohani jemaat agar tetap mematuhi aturan pemerintah yang tidak bertentang dengan Firman Tuhan.

Di dalam situasi social distancing covid 19, pendeta juga sebagai pengubah pola pikir jemaat kepada hal yang positip. Pola pikir jemaat yang positip melihat masalah covid 19 corona merupakan ujian dari Allah. Peran ini sesuai dengan peran yang disampaikan oleh PGI (tempo: 2020) untuk berpikiran positip. Pendeta membangun pola pikir positip jemaat sehingga jemaat tidak cemas dalam hidupnya. Pola pikir positip Jemaat sampai kepada taraf bahwa wabah ini akan berakhir.

\section{Sebagai Pemotivasi Jemaat melakukan sesuatu yang berbeda.}

Selama ini warga jemaat lalai akan kebersihan diri dan rohaninya, sehingga melalui peristiwa wabah covid 19 jemaat melakukan sesuatu yang berbeda untuk menjaga kesucian tubuh dan spiritual. Seorang pendeta berfungsi sebagai pemotivasi jemaat melalukan sesuatu yang berbeda dengan rajin mencuci tangan dan yang paling besar membersihkan diri. Sedangkan kepada hal yang rohani/spiritual Pendeta mengingatkan kepada jemaat supaya tetap berjaga jaga supaya jangan dikotori oleh hawa nafsu dan iblis. Yesus memberi nasehat, "Jagalah dirimu, supaya hatimu jangan sarat oleh pesta pora dan kemabukan serta kepentingan-kepentingan duniawi dan supaya hari Tuhan jangan dengan tiba-tiba jatuh ke atas dirimu seperti suatu jerat.” (Lukas 21:34)

Berjaga-jagalah senantiasa sambil berdoa, supaya kamu beroleh kekuatan untuk luput dari semua yang akan terjadi itu, dan supaya kamu tahan berdiri di hadapan Anak Manusia." Lukas 21:36 Yesus mengatakan, "Apabila semuanya itu mulai terjadi, bangkitlah dan angkatlah mukamu, sebab penyelamatanmu sudah dekat." Lukas 21:28. Pendeta mengingatkan jemaat tetap berjaga jaga terhadap godaan sijahat yang kaan menghancurkan kehidupannya. 


\section{Sebagai Pengingat Akan Kasih Allah}

Pendeta berperan sebagai pengingat kasih Allah dalam kehidupan Jemaat. Biarpun pandemic corona ini begitu dahsyat tetapi bahwa Allah tetap mengasihi seluruh jemaat. Pendeta mengingatkan akan penyertaan Allah bagi Jemaat. Pendeta mengingatkan penebusan Allah di dalam Yesus Kristus bagi Jemaat. Minirth -Meier (1990:219) menyatakan: kepada orang yang memiliki kecemasan maka akan ditekankan tentang Allah mengasihiMu dan Kasih Allah memberikan Asuransi keselamatan.

\section{Sebagai Pengembang Kepercayaan}

Pasaribu (2013:9) menyatakan mengembangkan kepercayaan dan pemikiran bahwa Allah menciptakan orang lain dalam arti dapat membantu dan menolong pribadinya untuk menyelesaikan kecemasannya. Selanjutnya Pasaribu (2013:9) menyatakan iman percaya kepada Tuhan adalah kunci mengatasi kecemasan.

\section{Sebagai Gembala}

Pasaribu (2012:20) menyatakan Tugas gembala adalah tugas pastoral. Pendeta sebagai pastor berarti pendeta sebagai gembala. Seorang Pendeta sebagai gembala harus memiliki pribadi yang hanya memberi sesuatu (sentiment love) tetapi sanggup mengasihi dalam arti positip (redemptive love), kasih yang menyelamatkan dan membebaskan. Pendeta mengembalakan warga jemaatnya melalui WA ataupun telepon. Kemudian tugas pengembalaan pendeta dengan mengunjungi Jemaat disaat social distancing biarpun menjaga jarak, di depan pintu dengan mengatakan: Tuhan Yesus mengasihimu dan menjauhkan darimu penyakit corona.

\section{Sebagai Pendoa}

Pendeta sebagai pendoa, mendoakan warga jemaat dalam segala pergumulan dan hidupnya. Pendeta harus siap membawakan dalam doa pribadi secara rutin, jika warga jemaat memasukkannya sebagai pokok doa dalam ibadah di rumah. Pendeta mendoakan seluruh warga jemaatnya di situasi social distancing.

\section{Sebagai Pensharing Firman Tuhan.}

Sebagai pendeta, tanggungjawab kita yang paling mendasar adalah untuk memberitakan Firman (2 Timotius 4:2) Peran Pendeta sebagai pensharing firman Tuhan. Dalam buku The Christian Counselors handbook (1987:72) menyatakan ganti kecemasan dengan pertumbuhan iman. Iman bertumbuh dari pendengaran Kabar baik, kabar Allah tentang Kristus.

\section{KECEMASAN KARENA VIRUS COVID 19 CORONA}

Masalah virus covid 19 corona yang berkepanjangan menimbulkan kecemasan jemaat dalam hidupnya. Ada kecemasan mengenai masalah ekonomi, kecemasan masalah pekerjaan dan masalah mengenai kesehatan. Kecemasan yang paling besar adalah soal kematian. Kecemasan ini membuat 
warga jemaat tidak tenang. Dalam Tribun news (2020/3/18) menyatakan kecemasan dapat menimbulkan ketakutan dan berujung pada gangguan konsentrasi.

Kecemasan adalah masalah kejiwaan yang tidaktenang, dimana gejalanya dibarengi debaran jantung.Kata kecemasan sering disebut dengan phobia. Dan kecemasan dapat timbul sebagai reaksi bahaya yang benar benar ada maupun yang sebenarnya tidak ada (hasil dari imajinasi saja. Pasaribu (2013:8) menyatakan penyebab kecemasan ialah ancaman, konflik, ketakutan dan kebutuhan yang tidak terpenuhi. Kemudian Antony \& Swinson (2000:6) menyatakan : Kecemasan adalah respon yang tepat terhadap ancaman, tetapi kecemasan dapat menjadi abnormal bila tingkatannya tidak sesuai dengan proporsi ancaman, atau bila datang tanpaada penyebabnya. Kecemasan melibatkan perasaan, perilaku, dan respon-respon fisiologis. Selanjutnya Semiun (2006) mengemukakan bahwa simtom-simtom kecemasan adalah 1) simtom suasana hati berupa perasaan tegang, panik, depresi dan sifat mudah marah; 2) simtom kognitif yang diperlihatkankan melalui kekhawatiran dan keprihatinan mengenai bencana yang diantisipasi oleh individu; 3) simtom somatik yang terbagi menjadi simtom langsung berupa keringat, mulut kering, bernapas pendek dan otot terasa tegang dan apabila kecemasan berkepanjangan, simtom-simtom tambahan seperti tekanan darah meningkat secara kronis, sakit kepala dan gangguan usus (kesulitan dalam pencernaan dan rasa nyeri pada perut) dapat terjadi; 4) simtom motor berupa tidak tenang, gugup, kegiatan motorik menjadi tanpa arti dan tujuan, misalnya jari-jari kaki megetuk-ngetuk dan sangat kaget terhadap suara yang terjadi secara tiba-tiba.

Secara khusus wabah virus covid 19 Corona membuat warga jemaat memiliki kecemasan kematian. Yalom (1980) Sifat kematian yang tidak dapat diprediksi mampu memicu rasa prihatin, takut dan rasa cemas. Kemudian Cicirelli (2002) Kecemasan menghadapi kematian merupakan fenomena umum yang terjadi pada manusia di segala rentang usia dan dapat dipandang sebbagai motivasi dasar dari perilaku manusia. Cavanaugh \& Blanchard (2011) menyatakan kecemasan menghadapi kematian sulit untuk didefenisikan karena memang pada kenyataan membuat manusia tidak nyaman.

\section{METODOLOGI PENELITIAN}

\section{Populasi dan Sampel}

Yang menjadi populasi dan sampel dalam penelitian penulis adalah berfokus hanya warga jemaat yang mendapat pelayanan Pendeta secara online. 


\section{Teknik Pengumpulan Data}

Natsir (1988) menyatakan dalam beberapa penelitian dapat mengunakan beberapa teknik pengumpulan data yang berkaitan dengan pokok yang penulis bahas, yaitu literatur, survei dan wawancara. Maka metode yang digunakan penulis adalah metode kualitatif dengan teknik pengumpulan data; Pengumpulan data yang dilakukan melalui wawancara online (via telepon atau WA).

Usman Rianse dan Abdi (2011:15) Skala Guttman menyatakan penyusunan mengunakan kuesioner atau angket dilakukan dengan mengunakan alat ukur berupa lembar kuesioner berupa data interval atau rasio dikotomi (dua alternatif) yaitu ya atau tidak. Dengan rumus $\mathrm{K}=1-\mathrm{e} / \mathrm{n}$. (K=Koefiesien hasil, $\mathrm{e}=$ yang menjawab ya. $\mathrm{N}=$ jumlah populasi

Pertama, penulis melakukan kajian pustaka yaitu melalui buku-buku yang berhubungan dengan peran Pendeta dalam Mengatasi Kecemasan Jemaat GKPI Onan Runggu di situasi virus covid 19 Corona. Kedua, menyebarkan angket melalui wa ke populasi. Ketiga mengolah data hasil angket.

\section{Teknik Analisis Data dan Pembahasan}

Data yang diperoleh dianalisis oleh penulis untuk diuji kebenarannya melalui suatu wawancara yang telah penulis lakukan kepada responsden dan akhirnya diperoleh data tentang bagaimana peran Pendeta dalam Mengatasi kecemasan Jemaat GKPI Onan Runggu Resort Onan Runggu di Tapanuli Utara Sumatera Utara di situasi social distancing. Kemudian penulis menganalisis data tersebut, lalu mengolah dan menyimpulkannya dalam bentuk uraian.

\section{ANALISA DATA DAN HASIL PENELITIAN}

\section{Analisis Interpretasi Data}

\section{Sebagai Pengubah Pola Pikir Jemaat}

Pertanyaan pertanyaan yang diajukan melalui angket kepada jemaat yang berisi apakah pendeta mengubah pikir warga jemaat secara positip melihat suasana social distancing? Apakah Pendeta menyatakan bahwa Allah bekerja dalam situasi social distancing ini ? Warga Jemaat yang menjawab ya sekitar $90 \%$.

\section{Sebagai Pemotivasi melaksanakan sesuatu yang berbeda}

Dari pertanyaan apakah memotivasi melaksanakan sesuatu yang berbeda misalnya mencuci tangan dan membersihkan diri? Kemudian apakah Pendeta memotivasi untuk menjauhkan diri dari 
hawanafsu dan keinginan daging yang dapat mengotori diri, maka $80 \%$ warga jemaat menjawab ya.

\section{Sebagai Pengingat akan Kasih Allah}

Dalam pertanyaan tentang peran Pendeta sebagai pengingat akan Kasih Allah yaitu: Apakah Pendeta selalu mengingatkan bahwa Allah masih mengasihi umatNya baik dalam suasana social distancing? Apakah kasih Allah akan menyelamatkan umatnya dari kecemasan besar ini ? $80 \%$ warga Jemaat menjawab ya.

\section{Sebagai Pendoa}

Pertanyaan kelima berkisar pada peran Pendeta sebagai seorang Pendoa. Dari hasil wawancara, 80 $\%$ warga jemaat yakin mengatakan bahwa pendeta selalu mendoakan warga jemaatnya. Bahkan mereka secara rutin memasukkannya sebagai pokok doa dalam ibadah di rumah melalui WA group Ruas GKPI Onan Runggu.

\section{Sebagai Gembala}

Pertanyaan mengenai gembala: apakah Pendeta sebagai gembala mengunjungi saudara di masa social distancing biarpun itu sebatas hanya di halaman rumah ? Apakah Pendeta menyapa saudara pada masa pengembalaan? $75 \%$ warga Jemaat menyatakan ya.

\section{Pensharing Firman Allah}

Pertanyaan yang dibuatkan yaitu: APakah Pendeta mensharing Firman Allah setiap harinya? Apakah Firman Allah ini dikaitkan dengan mengatasi kecemasan disituasi social distancing covid 19? Dari pertanyaan ini $85 \%$ warga jemaat: ya.

\section{Sebagai Pengembang Kepercayaan}

Pertanyaan sebagai pengembang kepercyaa: Apakah Pendeta mengembangkan kepercyaan saudara di situasi social distancing covid $19 ? 70 \%$ warga jemaat menjawab ya..

\section{KESIMPULAN HASIL ANALISIS}

Adapun yang merupakan kebutuhan dari warga jemaat dalam mengatasi kecemasan melalui wawancara yaitu: 
Pertama, warga jemaat membutuhkan Pendeta yang dapat mampu memberikan perubahan pola pikir warga jemaat. Pendeta sebagai pemola pikir warga jemaat mencapai 90\% . Untuk itu pola pikir positip akan mengatasi kecemasan warga jemaat di situasi social distancing.

Kedua, kebutuhan pengembangan kepercayaan harus ditingkatkan sehingga kepercayaan warga jemaat meningkat. Dari hasil yang di dapat $75 \%$, ini menunjukan yang paling rendah. Dengan mempercayai Firman Tuhan yang dishare pendeta maka warga jemaat dapat mengatasi kecemasan di situasi social distancing covid 19.

Ketiga, kebutuhan warga Jemaat dari pendeta terus dipertahankan. Dari hasil yang didapatkan $85 \%$. Pensharing Firman Allah juga melalui ibadah di rumah. Warga jemaat akan melakukan ibadah dan persekutuan di tengah tengah keluarga. Sehingga di tengah tengah keluarga saling mengautkan, mendukung dan menghibur.

Keempat, pendeta sebagai pendoa hal lain juga merupakan kebutuhan warga Jemaat yaitu didoakan, selain iman yang yang besar kepada Tuhan untuk mengendalikan hidup mereka, warga jemaat yakin bahwa kuasa doa memegang peranan yang penting dalam merekasituasi wabah virus covid 19 coronaKeenam, kebutuhan daripada remaja adalah gembala. Remaja membutuhkan gembala yang mengembalakan dirinya menjadi domba yang baik. Dari hasil pengembalaan seorang pendeta maka remaja akan damai, tenang, dalam kebenaran dan kasih.

Berdasarkan atas seluruh uraian di atas mengenai peran pendeta dalam mengatasi kecemasan jemaat di situasi social distancing covid 19 mencapai 80,85 \%, maka dapat disimpulkan seorang pendeta yang memiliki peran dalam mengatasi kecemasan jemaat di situasi social distancing covid 19. Pendeta dalam perannya harus memilikiempati kepada jemaatnya. Pendeta yang betul-betul memiliki hati untuk pelayanan remaja dan bukan hanya sebagai pelayanan untuk mengisi waktu luang atau kekosongan formasi pelayanan saja.

\section{KESIMPULAN}

Berdasarkan penelitian yang telah dilakukan dapat disimpulkan bahwa melalui peran Pendeta dalam mengatasi kecemasan jemaat berhasil menurunkan tingkat kecemasan dengan mengubah pemikiran negatif menjadi alternatif pemikiran yang lebih positif dan rasional serta iman. Pemikiran positif dan rasional serta dapat membuat subjek merasa lebih nyaman dan tidak cemas, akibatnya tidak lagi berpikir negative tentang situasi social distancing covid 19. Warga Jemaa menjadi lebih berani dan percaya diri ketika menghadapi berbagai situasi social distancing covid 19 yang selama ini mereka cemaskan. Beberapa peran pendeta telah diterapkan seperti pendoa, pensharing Firman Allah restrukturisasi kogntif, gembala, memotivasi kepada perbuatan baru, 
dirasakan subjek sebagai hal yang sangat membantu warga jemaa mengatasi kecemasannya. Pensharing Firman Allah sebagai teknik yang kurang diminati, namun dapat membantu subjek dalam mengurangi sensasi rohani yang dirasakan. Pengembangan kepercayaan merupakan hal yang dirasa subjek sangat membantu mereka berpikir positif agar tidak muncul kecemasannya dan berani menghadapi situasi social distancing yang sesungguhnya. Implikasi dari penelitian ini adalah bagi peneliti selanjutnya yang akan melakukan penelitian dengan peran Pendeta dalam mengatasi kecemasan warga jemaat perilaku dapat dilakukan dengan setting kelompok.

\section{DAFTAR PUSTAKA}

Antony, M. M., \& Swinson, R. P. (2000). Shynes \& social anxiety workbook. Canada New Harbinger Publication, Inc.

Butler, G. (1999). Overcoming social anxiety and shyness. London: Constable \& Tony Robinson, Ltd.

The Christian Counselor Handbook, Virginia: Tyndale House Publisher Inc, 1987

Cavanaugh, J. C., \& Blanchard Field, F(2011) Adult development and aging Belmont: Thompson Learning

Cicirelli, V. G. (2002). Fear of death in older adults: Prediction From Teror Management of Gerontology, 57(4), 358-366,doi:10.1093/geronb/57.4358.

Minirth, Frank, Paul meier, Richard Meier dan Don Hawkins, The Healthy Chritian Life:

Michigan: Baker Book House, 1999.

Moh. Natsir, Metode Penelitian (Jakarta: Ghalia Indonesia, 1988), 211

Pasaribu, Andar Gunawan Pelayanan Pastoral Konseling Yang Dinamis Di Gereja dan Sekolah, ( Medan Mitra, 2012),

Pasaribu, Andar Gunawan, Cara Mengatasi Ketika Berhadapan dengan 35 Masalah,

Medan: Penerbit, Partama Mitra Sari: 2013.

Semiun, Y. 2006. Kesehatan Mental 1. Yogyakarta: Penerbit Kanisius

Yalom, I. (1980). Existential Psychoteraphy, New York:Basic Books.

https://hariansib.com/Agama-Kristen/Teologi-Virus-Corona

https://nasional.tempo.co/read/1316409/persekutuan-gereja-keluarkan-imbauan-untuk-umat-soalvirus-corona/full\&view $=$ ok

https://batam.tribunnews.com/2020/03/18/catat-simak-9-langkah-atasi-kecemasan-selama-wabahcorona-melanda 